\title{
Herbert Hoover and the Smear Books, 1930-1932
}

\author{
Rosanne Sizer
}

As the stock market crashed in late October 1929 and the economy slid into the Depression, the presidential campaign continued without intermission. Herbert Hoover, who in 1928 had seemingly personified the American dream, became besieged by criticism for his failure to prevent economic disaster. Democrats eagerly seized the opportunity to humble the once god-like Hoover by associating him personally with the Depression's tragic effects. Other criticism came from members of Hoover's own party who were anxious to jettison the man they now considered to be a political liability. This intense political atmosphere proved to be an ideal breeding ground for an outright smear campaign against Hoover. Although not orchestrated by any one person or party, a plethora of books appeared between 1930 and 1932 which made libelous assaults on Hoover's pre-presidential years. These books attempted to play on the emotions and prejudices of a populace fearful of total economic collapse. In their attempts to vilify the president, the authors accused Hoover of myriad black deeds: from dabbling in a virtual white slave market to manipulating mining accounts to defraud the public, from working as the assistant to a land shark in Oregon to selling World War I relief to the Germans and, in so doing, prolonging the war.

Although the exaggerated charges had little real influence at the polls, Hoover and his associates felt the sting of these attacks personally and actively refuted them. Hoover's response was conditioned by his relative political inexperience, his sensitive nature, and the intensely loyal men with whom he surrounded himself. Perhaps indicative of Hoover's nature, once a campaign of refutation was accepted, it was conducted with the 
utmost logic and an engineer's skill and sought to appeal to the rational side of human nature at a time when economic crisis prompted an irrational search for scapegoats. One of Hoover's recent biographers could have been speaking of the refutation campaign when he wrote, "It was the engineer in him, perhaps, that trusted so much to autonomous intelligence applied to understandable materials, discovering solutions that other intellects would impersonally accept." ${ }^{1}$ Unfortunately for Hoover, calculated reason and logic had little to do with the smear books of 1930 to 1932 .

For all of Hoover's sensitivity to personal assaults, he was by no means a stranger to political criticism; early encounters with the rough-and-tumble of American politics helped to condition his later responses to the smear books. Throughout the early 1920s, Hoover was plagued by a persistent whispering campaign concerning his part in a famous legal suit in 1905 (in which he allegedly swindled the Chinese government of valuable mineral resources), casting aspersions on his un-American status and obsequious relationship with Britain, and making attacks on his wartime relief activities.

Friends counseled the president not to dignify these rumors with a response. In a 1921 letter concerning the Chinese mining case, Arthur Train, who would work with Hoover on these matters for over a decade, cautioned, "In a matter of this sort, it is no use attempting to prove a negative. No matter what you do or what fact you establish, you cannot silence every dissatisfied stockholder and your enemies do not care what facts there are as long as they can misconstrue them." 2 Prophetically Hoover ignored this advice about the futility of countering spurious charges.

Even though in most quarters he was highly acclaimed, Hoover made active efforts to refute the early charges. He enlisted his loyal supporters, including the ever-faithful Edgar Rickard and Lawrence Richey, to collect information that might be utilized if printed attacks appeared. Agents were dispatched to London, the European continent, and China to procure

1. David Burner, Herbert Hoover: A Public Life (New York, 1979), 255.

2. Train to Hoover, 9 February 1921, "Misrepresentations file-Chinese Mining Suit," Herbert Hoover Papers, Herbert Hoover Presidential Library, West Branch, Iowa (hereafter cited as HHP). 
evidence which would clear Hoover of any alleged wrongdoing and, if possible, to discover the sources of the calumny. After much consideration, Hoover and his associates concluded that the source of the 1920s rumors was the virulently Anglophobic Hearst faction of the Republican party. ${ }^{3}$

These personal assaults were exceptions throughout the 1920 s-plaudits were customary when one spoke of Herbert Hoover. He appeared to embody the best of American life: he combined an extraordinarily successful career as a mining engineer with a highly acclaimed reputation for public service as director of World War I relief activities. Charles Michelson, appointed publicity director of the Democratic National Committee in 1929, probably exaggerated only slightly when he wrote that Hoover in 1928 was ". . . an almost supernatural figure whose wisdom encompassed all branches, whose judgement was never at fault, who knew the answers to all the questions, and who could see in the dark."4

With the onslaught of the Depression, however, Hoover's public image began to change. The publicity bureau of the Democratic National Committee, under the aegis of the politically astute Michelson, undertook a massive campaign to discredit Hoover. Michelson enlisted the aid of Democratic senators and representatives in casting doubts on Hoover's ability to cope with the Depression. ${ }^{5}$ Several books also appeared-among them Robert S. Allen's Why Hoover Faces Defeat and John L. Heaton's Tough Luck-Hoover Again-accusing Hoover of many character failings and questioning his competence as president. A passage from the Allen book reveals the tenor of these charges: "The collapse and failure of Herbert Hoover is the result of basic and fundamental causes-his abysmal incompetence, his pettiness and deviousness in personal relations, his shocking callousness to tragic suffering among millions of his countrymen, his timidity, his plain ignorance, and his blind reactionism." ${ }^{\prime 6}$

Not surprisingly, Hoover and his supporters railed against

3. Hoover to John Board, 31 January 1921, “Misrepresentations file-Chinese Mining Suit;" HHP.

4. Charles Michelson, The Ghost Talks (New York, 1944), 27.

5. Ibid., 33.

6. Robert S. Allen, Why Hoover Faces Defeat (New York, 1932), 8. 
what they considered to be a "mud slinging campaign" by their Democratic opponents. They charged Michelson and his crew with attempting to make political capital out of public misery. They countered the charges by listing the multitudinous accomplishments of Hoover's presidency and by exposing the maladroit techniques that the Democrats used in their defamation of the president. The sting of Michelson's campaign is apparent in Hoover's Memoirs, as Hoover accused the publicity director of interjecting a new element into American politics: the unprincipled use of personal assaults. ${ }^{7}$

It was perhaps inevitable, given the mounting fervor of the campaign for the presidency, that less scrupulous men would seek to defame Hoover for personal profit or vengeance. Thus, from 1930 to 1932, six unmitigated smear books about Hoover were published: The Great Mistake, by "John Knox"; The Strange Career of Mr. Hoover Under Two Flags, by John M. Hamill; Hoover's Millions and How He Made Them, by James J. O'Brien; The Rise of Herbert Hoover, by Walter Liggett; Herbert Clark Hoover: An American Tragedy, by Clement Wood; and a two-volume biography of Hoover by E. Haldeman-Julius of Girard, Kansas. ${ }^{8}$

JoHn Hamill's work was by far the most important, as it set the general tenor, provided the "documentation," and outlined the areas of attack which the other books were to follow. Hamill began his work, in conjunction with James O'Brien, near the end of the presidential campaign of 1928. After Hoover's resounding defeat of $\mathrm{Al}$ Smith, James O'Brien had volunteered his services to John Raskob, the source of money behind the Democratic National Committee. O'Brien offered to gather damaging evidence against Hoover to be used in the next presidential election. Although Raskob gave O'Brien his blessing, it is not altogether clear where $\mathrm{O}^{\prime} \mathrm{Brien}$ obtained financing for the

7. Herbert Hoover, Memoirs, 3 vols. (New York, 1952), 2:218; press release draft, 1 September 1930, "Misrepresentations file--Democratic National Committee," HHP.

8. Copies of the books by John Hamill, James O'Brien, Walter Liggett, and Clement Wood are available at most major libraries. I was unable to locate copies of the books by "John Knox" and E. Haldeman-Julius. 
venture. (Some have connected him with a Mr. Kenny of Tammany Hall, others with a Mr. Halloran of Long Island.) O'Brien soon teamed up with Hamill, an Irish-born English national. Hamill was sent to London, where he was to delve into Hoover's mining career. He spent several months in London in a chronically impecunious state and returned to the United States by October $1929 .{ }^{9}$

With Hamill's return to the United States, the relationship between the two men became severely strained. Hamill suspected $O^{\prime} B$ rien of lying about his strong political pull and vast wealth. Fearful that O'Brien was playing him for a fool, Hamill cast about for other opportunities to use his new knowledge of Hoover's past. He first turned to the Hoover people, apparently hoping that they would pay him for not revealing his allegedly damning evidence. Claiming that he suffered from a guilty conscience, Hamill scheduled a series of conferences with Edgar Rickard from December 1929 through the fall of 1930. Rickard and his associates were understandably wary of Hamill's protestations of penitence. They had the FBI check into his background and monitor his current activities; they recorded his telephone calls and private meetings. After much hedging on both sides, the tenuous negotiations between Hamill and the Hoover forces were broken off. ${ }^{10}$

Unsuccessful in his extortion attempts, Hamill endeavored to find a publisher for his book and succeeded in locating Samuel Roth, alias William Faro, a thrice-convicted dealer in obscene literature. Roth's previous publications had included such classics as Venus in Furs and Celestine-Diary of a Chambermaid. He was also noted for having reprinted James Joyce's Ulysses and D. H. Lawrence's Lady Chatterly's Lover, without the authors' knowledge or consent. Hamill's book, The Strange Career of Mr. Hoover Under Two Flags, was finally published on September 26, 1931. Roth and Hamill hoped to

9. John Hamill, affidavit, 4 June 1932, "Misrepresentations file-Hamill Affidavit," HHP; notes on phone call, Edgar Rickard and John Hamill, 25 August 1930, "Misrepresentations file-Rickard Memoranda," HHP.

10. Hamill affidavit; John Hamill to James O'Brien, 4 September 1930, "Misrepresentations file-Memoranda," HHP; memoranda, December 1929-November 1930, "Misrepresentations file-Rickard Memoranda," HHP. 
garner from $\$ 100,000$ to $\$ 200,000$ from the book; their expectations were not realized. ${ }^{11}$

James O'Brien was enraged by Hamill's defection and by the Democratic National Committee's unceremonious rejection of his own manuscript. (O'Brien would later publish his book privately.) Hoping to get a share in Hamill's profits, $\mathrm{O}^{\prime} \mathrm{Brien}$, in late September 1931, filed suit against Hamill and Roth, attempting to obtain an injunction stopping the sale and distribution of their book. O'Brien claimed that Hamill had been in his employ while collecting material for the book and had therefore stolen the evidence against Hoover. In his December 16, 1931 decision, Justice Cotillo of the district court of New York granted the injunction, but devoted the largest portion of his decision to chastising the author for attempting to libel a public official. In the final case reviewing the injunction in early 1933, New York Supreme Court Justice Schmuck threw the question of ownership of the book and documents out of court, declaring that the sordidness of the entire proceedings divested both parties of a claim to equity. Schmuck wrote in his scathing decision, "To dignify this litigation with serious consideration would be to clothe it with decency, gravity, and materiality. . . We believe that both parties are guilty of attempting to deceive the American public." 12

If the activities surrounding publication of this book were sordid, its contents did not lag behind. It opened with a note from the publisher assuring readers that documentary evidence supported every syllable printed in the "extraordinary work," and intimating that the Hoover partisans had resorted to destroying damaging evidence and, failing to do so completely, had attempted to thwart the book's publication. Hamill protested that he was merely doing his patriotic duty in disclosing the painful truth, in an effort to counter the misrepresentations generated by Hoover's extensive propaganda machine and host of sycophantic "liographers." 13

11. Harold Goldman to George Barr Baker, 26 October 1931, "Misrepresentations file-Samuel Roth," HHP.

12. Justice Schmuck's decision, 12 January 1933, in "Misrepresentations file-O'Brien v. Hamill," HHP; Justice Cotillo's decision, 13 December 1931, in "Misrepresentations file-O'Brien v. Hamill," HHP.

13. John Hamill, The Strange Career of Mr. Hoover Under Two Flags (New York, 1931). 
Hamill traced Hoover's career from his birth in Iowa in 1874 to the end of the Belgian relief operations in 1918. He described a career of unmitigated evil: First, he cast aspersions on Hoover's character by portraying him as secretive, antisocial, woefully ignorant and uncouth, and completely without conscience and moral training. Hoover's subsequent career was determined with his involvement as an adolescent in his uncle's land-shark enterprise, the Oregon Land Company. After an undistinguished career as a geology student at the newly opened, glorified high school, Stanford University, an ill-equipped Hoover embarked on a career as a mining engineer.

The largest portion of The Strange Career of Mr. Hoover was devoted to an exhaustive discussion of Hoover's misdeeds as a mining engineer, stock promoter, and financial "insider." In his assessment of Hoover's mining career, Hamill depicted a man with a total disregard for human life and suffering. Hamill accused Hoover of importing slave-like foreign labor in both Australia and South Africa and of cutting costs by skimping on underground support timbers. In all mines under Hoover's control, the workers' death rate rose immeasurably. Hamill expounded, "These men were murdered in the lust for gold, sacrificed on the altar of greed."14

This obdurate lack of concern also characterized Hoover's business enterprises in Hamill's view. Throughout his career, Hoover employed various devious means to assure his own financial success. In this respect the Chinese mining case of 1905 provided important evidence. Hoover traveled to China to assist the Chinese in tapping their expansive mineral resources. Instead, he secured the valuable Kaiping mines for himself and his associates. Hoover's malfeasance was exposed in a celebrated court case in London when the "defendant" Hoover and his cohorts were ordered to give the Chinese their rightful voice in the mines' management. This case instilled in Hoover the belief that all those who invested in his mines were idiots who deserved to be cheated. Through bribery, altered accounts, inflated mine assessments, phony directorates, and skillful manipulation of the mining press, Hoover built a wide-flung mining empire. Hoover's mode of operation was dramatically

14. Ibid., 116. 
described in the case of the tin mines in Burma: "It was robbery with a capital R. But not openly in daylight. Secretly, and by stealth. It was burglary behind a mask, and that mask was the syndicate." 15

Hamill even cast doubts on Hoover's national loyalty. After years of living outside of the United States, he charged, Hoover was American by birth only. Moreover, Hoover had renounced his citizenship by his inclusion on the Kensington voters' list. So unknown was Hoover in the United States that an exhaustive background check had to be conducted in 1914 to familiarize Americans with the self-appointed relief director.

Hamill's indictment culminated in an examination of Hoover's wartime relief activities. Far from being a charitable enterprise, Belgian relief was another of Hoover's moneymaking ventures-the most profitable one. Hamill protested that he was merely setting the record straight by exploding the myth of the "Great Humanitarian" so assiduously created by his hireling propagandists. Hamill succinctly stated his view in one passage:

The simple fact of the matter is that Hoover had nothing to do with the organizing of the Belgian relief at all, that Belgium did not need any relief other than the ordinary soup kitchen. . . . The whole scheme of Belgian relief was planned by Germany for the purpose of securing the enormous food supplies of Belgium. The Belgian relief, regarded by the Belgians as a nuisance rather than a savior, was the cause of the prolongation of the dreadful war. . . . ${ }^{16}$

Hamill's diatribe was so shrill, so completely one-sided that it almost evoked sympathy for the much reviled Hoover-a consequence far from the author's intent. Hamill interchanged startling disclosures with moralistic platitudes and catchy phrases such as "... he came, he saw, and he coveted." Hamill's use of evidence bordered on being ridiculous. For example, he presented partial, undated photostatic copies of articles from obscure mining journals as irrefutable proof of his allegations. In one instance, Hamill described the misdeeds of a "Herbert Clark Emery" in Argentina, leading readers to believe

15. Ibid., 259.

16. Ibid., 306. 
that Emery was an alias for Hoover. In fact, a mining engineer named Herbert Clark Emery did live in Argentina at the time. Hamill's most ingenious and oft-repeated device was tinkering with the chronology of events, blaming Hoover for the collapse of companies long before or after his association with them. Despite his use of such clever ploys, it is difficult to believe that anyone could have believed the poorly stated and selfcontradictory charges.

The other important smear book, Walter Liggett's The Rise of Herbert Hoover, was more sophisticated: the author at least conceded that Hoover had some good qualities and notable achievements. Liggett wrote:

There is a tendency in some quarters to deny that Hoover possesses great ability. He has revealed some amazing shortcomings-particularly since he became President-but there can be no question that as a geologist, mine manager, promoter, and financier he not only had remarkable natural aptitude, but made the most of his opportunities by unflagging study. ${ }^{17}$

Liggett even vindicated Hoover of many of Hamill's accusations. But for Liggett, Hoover's abilities were greatly overshadowed by his appalling moral obtuseness, selfishness, intellectual intolerance, and total disregard for the rights of others.

Like Hamill, Walter Liggett swore by the accuracy of every charge made in his book. In fact, Liggett plagiarized Hamill's book heavily, particularly in chapters dealing with Hoover's mining career. Liggett deviated from Hamill in discussing Hoover's activities after Belgian relief. Liggett had been active in a postwar relief organization, the Friends of Soviet Russia. This pro-Soviet organization had been all but eliminated when Hoover took over direction of all Russian relief operations in $1918 .^{18}$ Liggett, from this confrontation, apparently developed a life-long resentment against Hoover, bolstered by his loathing for what he considered to be Hoover's extreme reactionism.

Liggett's book accused Hoover of shameless favoritism and

17. Walter Liggett, The Rise of Herbert Hoover (New York, 1932), 171-172.

18. Rickard to S. E. Nicholson, 9 March 1932, "Misrepresentations file-Walter Liggett," HHP. 
profiteering as food administrator and of using food to blackmail the Germans and Austrians to surrender in the closing months of World War I. Liggett became increasingly rabid as he revealed Hoover's relief activities in Russia. He charged Hoover with using relief funds to aid the White Russians and Poles in their efforts to topple the embryonic Bolshevik regime. ${ }^{19} \mathrm{He}$ also credited Hoover with bringing about the Russian famine of 1921 to 1923, which resulted in the deaths of five million innocent Russians. All of this senseless tragedy was the result of Hoover's unconscionable vendetta against the Bolshevik government for the confiscation of his rich mining property in Russia. Hoover's subsequent career as secretary of commerce and president gave Liggett little reason to alter his assessment. Although he stopped short of blaming Hoover for the onslaught of the Depression, Liggett contended that he could have done more to mitigate its impact and ameliorate the dreadful conditions under which his fellow Americans suffered.

Press reaction to the smear books was generally unfavorable. In fact, a blanket of editorial silence muted the matter in most scholarly journals and reputable newspapers. Reviews that did appear either condemned the libel of the president or seriously questioned the accusations and urged the president to respond. William Allen White, in a review of Liggett's book in his Emporia (Kansas) Gazette, defended Hoover by condemning the book as simple hate literature, propaganda of no real value. Other journals, such as New York's Outlook magazine, refuted the charges made in the smear books and disclosed the contemptible backgrounds of the authors. The New Republic conceded that the president would appear ridiculous and undignified in filing a libel suit against an obscure writer of unsavory repute, but expressed the hope that Hoover's friends would present the facts and, in so doing, undertake a noble act of public service. The Chicago News asserted that the books carried with them their own refutation, and cautioned Hoover against stooping to repudiate them. The News even ventured to guess that the books were having a boomerang effect, enlisting popular sympathy for Hoover. The New Haven Times was thus atypical when it depicted the Hamill book as

19. Ibid., 269. 
"...the most sensational exposé this reviewer has ever seen .... We can not see how Hoover can refrain from insisting upon legal action to clear his name." 20

Sales of the smear books proceeded unevenly. John Hamill's The Strange Career of Mr. Hoover Under Two Flags was the only one in widespread circulation-even at $\$ 3.75$ per copy, an extraordinarily high price. Late in 1931, Hamill's book made appearances on nonfiction best seller lists in New York, New Orleans, and San Francisco. (These lists, however, rated the best sellers of a collapsed book market.) $)^{21}$

IF THE PRESS was hostile to the smear books, it is not difficult to imagine the outrage with which Hoover and his associates greeted their publication. Although little direct evidence of Hoover's reception of the 1930s smears exists, his response may be inferred from his reaction to criticism earlier in his career and the reactions of his close associates, particularly the Belgian relief coterie. David Burner has developed a telling insight into Hoover's character: ". . . Hoover could not bear to be misread. It was as though there were two forces warring within him; the need of an orphan to show the world he had made good, which can be interpreted as a fear of failure, and the Quaker aversion to public tribute." 22

Hoover's ire over the smear books was not prompted merely by concern for his own reputation; he was also solicitous of the reputations of his friends. He was particularly protective of the cherished activities of the Belgian relief organization and the men who had helped run it. In a 1922 letter to President Warren Harding, Hoover had revealed his resentment of attacks on members of the Commission for the Relief of Belgium (CRB): "Furthermore, such statements in the face of the hardships that I know these men are enduring ... are enough to make my blood boil . . . [and] can emanate from no sort of soul except

20. Clippings, "Misrepresentations file-Press Reaction to Hamill Book and Train Article," HHP. Papers cited are: Emporia (Kansas) Gazette, 28 March 1932; Outlook, 9 December 1931; New Republic, 16 December 1931; Chicago News, 12 February 1932; New Haven Times, 24 October 1931.

21. Best seller lists, 19 November 1931, "Misrepresentations file-Press Reaction to Hamill Book and Train Article," HHP.

22. Burner, Hoover, 92. 
that of a skunk." 23 In his Memoirs, Hoover wrote of his association with Belgian relief with an almost reverent awe and of the men who volunteered for that service as representing the best qualities of American manhood. In his recollection of a 1938 reunion of relief workers, Hoover's writing became choked with emotion: "Every article in the room and every word revived memories of men who had risen to great acts and great days. Some way a great spirit flowing with human devotion flooded the room. ..." 24

Hoover's loyalty inspired equal loyalty in others; Hoover gathered around him a close-knit group of supporters, many of whom began their association with him during the early years. It is not surprising, then, that the individuals most incensed by the accusations made in the smear books were former members of the wartime relief organizations: men such as Edgar Rickard, Perrin Galpin, Lyman Brown, George Barr Baker, John Agnew, G. I. Gay, Will Irwin, and Walter Hope. To them also, the relief organizations were vivid memories if not living entities. In fact, the CRB was not officially liquidated until October 22, 1930, nearly sixteen years after its inception. Even then, the CRB Educational Foundation remained in operation, with Hoover as its spiritual head and Edgar Rickard as its energetic director. The educational foundation was organized to perpetuate the memory and the spirit of Belgian relief by dispensing grants in a reciprocal study program for Belgian and American scholars and by donating funds for rebuilding the University of Brussels. Former members of the CRB retained their professional ties through semi-annual meetings and luncheons; they formed a close-knit network providing social contacts, professional advancement, and financial aid. ${ }^{25}$

Thus, when the smear book authors attacked Hoover and his wartime relief activities, the men of the CRB took it as an assault not only on their leader, but also on the organization that they considered to be sacrosanct. Former CRB worker George Barr Baker demonstrated the attitudes of his colleagues

23. Hoover to Harding, 2 June 1922, "Misrepresentations file-Belgian Relief," HHP.

24. Hoover, Memoirs, 1:237.

25. Edgar Rickard diary, 22 October 1930, Hoover Library; Will Irwin, Herbert Hoover: A Reminiscent Biography (New York, 1928), 167-168. 
when he wrote: "The President's personality is still not well known to the public largely because he will never go in for hippodroming and bally-hoo. He has the quiet modesty of strength. Those who know him love him for it. It is always hard for me to speak of him without deep feeling."26 Baker wrote about the feared effects of the smear books: "If Hamill's charges in this respect are allowed to go uncontested, the organization which to all of us has been almost a religion will be smirched beyond hope." 27 The members of the wartime relief organizations would head the efforts to clear the president of charges of misconduct and to discredit the authors of the smear books.

If Hoover's associates were unified in expressing their indignation over the smear books, they were initially indecisive in deciding what measures, if any, would best refute the charges and what possible damage the books would do to Hoover's upcoming campaign. Of the men around Hoover, the former relief workers were the most convinced that the smear books would be eagerly seized by a scandal-loving public and consequently could do irreparable harm in the November elections. Most of the former CRB staff expressed the opinion that action should be taken to publicly refute the books, particularly the one by John Hamill. One incensed Hoover supporter went so far as to urge Hoover to press for legislation prohibiting the publication of books defaming the president and other high government officials. ${ }^{28}$

But not all of Hoover's supporters thought that active refutation of the smear books was necessary. For example, Hugh Gibson, wartime secretary of the American legation in London, cautioned that such an action would appear undignified and in any case ". . . it [the Hamill book] is so wild and fantastic it seems to me the only course is to treat it with the silent contempt it deserves. ${ }^{\prime 29}$ Although he was adamant in his

26. Baker to Rickard, n.d., "Misrepresentations file-Baker," HHP.

27. Baker memorandum, 3 October 1931, "Misrepresentations file-Baker," HHP.

28. Baker to John Lucey, 23 November 1931, "Misrepresentations file-Baker," HHP; G. I. Gay to Perrin Galpin, 16 October 1931, "Misrepresentations file-Galpin," HHP; Baker to Edgar Rickard, 2 June 1932, "Misrepresentations file-Hamill Book," HHP.

29. William Castle to Rickard, 1 December 1932, "Misrepresentations file-Hugh Gibson," HHP. 
defense of the president, Gibson feared that any action to refute the books would only draw attention to them and encourage similar works. William Castle agreed with Gibson's reasoning and suggested that Hoover take action only if solid evidence were uncovered implicating the Democrats in the books' publication. Even Hoover's press secretary, George Akerson, advised Hoover to ignore the books. Some of Hoover's supporters predicted that the smear books would strengthen Hoover's political position by enlisting public sympathy. ${ }^{30}$

Despite these warnings, the CRB men and some White House officials such as Lawrence Richey decided to proceed with a refutation campaign and a fully informed Hoover apparently gave his wholehearted support. The remaining problem was to select a mechanism for the refutation, hopefully one that would call the books into question without garnering them too much publicity. The first line of attack considered was legal action, a suit to be filed by one or more members of the CRB against the authors, particularly Hamill. In this effort, Edgar Rickard commissioned a prestigious New York law firm to prepare a brief for use in a possible libel action. But after lengthy deliberation, the court-action strategy was discarded. The CRB had not been sufficiently damaged to evoke a court decision suppressing the books; for example, Hamill had devoted only the last few pages of his book to exposing how the men of the CRB had become "rich by working for nothing." Herbert Hoover was the only real victim of the authors fabrications and he, of course, could not degrade himself by involvement in such a sordid legal case. ${ }^{31}$

After the idea of court action was discarded, the second phase of the refutation campaign began with a systematic collection of documents exonerating Hoover and careful monitoring of the books' sales. Letters were sent to newspapers nationwide disclosing the nature of the books and strongly suggesting that the papers refuse to print advertisements for them. Moreover, agents were sent to bookstores to obtain sales statistics. The efforts to stifle sales became almost comic when Hoover's supporters shared a limited number of books, fearful

30. Ibid.; Rickard diary, 15 August 1930.

31. Rickard diary, 1930-1932 passim. 
that if they bought even one more copy they might encourage another printing.

The effort to collect exonerating evidence was critical in case attacks generated by the books reached the floor of Congress, an arena in which Hoover was already undergoing monumental difficulties. ${ }^{32}$ The documentary evidence compiled by the researchers was extraordinarily convincing. The researchers were particularly pleased with a statement by Emile Francqui, the Belgian head of relief operations, which completely cleared Hoover of all charges of malfeasance. Many affidavits were secured concerning Hoover's mining and relief activities. G. I. Gay, the author of a book attesting to the scrupulous bookkeeping of the CRB, was hired to systematically dissect the Hamill book, to point out flaws in the author's arguments, and to gather evidence to refute them. Rickard acquired a statement by the auditors of the relief operations attesting to the veracity of the organization's accounts and praising the spirit of selflessness and integrity which characterized the entire relief effort. John Agnew traveled to London to delve into British mining records and, if possible, to locate the sources utilized by Hamill.

Once the documentary evidence had been amassed, the temptation to publicize it became nearly irresistible. Hoover's supporters now dreamed that they could silence misrepresentations of the president forever. Edgar Rickard wrote excitedly: " . . . some of the chief's friends . . . have been planning what I believe will be one of the most complete cleanups of scurrilous attacks that have been made, and could be used for time immemorial as an essay on the subject." ${ }^{33}$ The plan had to be executed quickly, though, to be early enough to influence the November elections, the overriding goal of the refutation efforts.

The grandiose plan had two parts: first, a short article stressing the irrefutable evidence as embodied in the affidavits, completely exonerating Hoover of any wrongdoing in his prepresidential career and second, a more detailed book that would

32. Perrin Galpin to Rickard, 19 October 1931, "Misrepresentations file-Galpin," HHP.

33. Rickard to Harry Bain, 9 December 1931, "Misrepresentations file-Train Article," HHP. 
systematically dissect the smear books, pointing out every deviation from the truth and eulogizing the president. In December 1931, Arthur Train, a lawyer and popular fiction writer, was enlisted to write the short article. Herbert Corey, a veteran political reporter, was selected to write the book. As a precaution, both men were indemnified by the CRB fund against possible libel action resulting from their essays. ${ }^{34}$

Arthur Train's article was slated to appear in Collier's magazine in February 1932 and a detailed agenda was developed for the dissemination of reprints. Inexpensive reproductions of the article were to be mailed as expeditiously as possible to former members of the American Relief Administration and its subsidiaries, the Belgian Fellows, key Hoover supporters in Europe and the Orient, the Hoover Engineers' Committee, "32" Club workers, Republican state committee workers, and all others on request. Expecting that the reprints would be in great demand, Rickard had 55,000 copies printed. Moreover, arrangements were made to have the article broadcast on the "Collier's Hour," a radio program, on February 14.

Rickard was extremely concerned that no effort be made to implicate the Democratic National Committee in publication of the smear books. He was therefore outraged by a statement made on December 18, 1931, in the New York Evening Post by Robert H. Lucas, executive director of the Republican National Committee, accusing the Democrats of inspiring and underwriting the smear books. ${ }^{35}$ From his contacts with Hamill and his investigations into the smear books, Rickard knew this was not true and warned Lawrence Richey in no uncertain terms against issuing statements of that kind. Rickard wrote, "When O'Brien presented the manuscript of the book and tried to get Kenny and Raskob to back him, they bodily threw him out and said they would have nothing to do with such trash." ${ }^{36}$ The matter was not mentioned in the press again.

Train's article, "The Strange Attacks on Herbert Hoover: A

34. Rickard to John Agnew, 21 January 1932, "Misrepresentations file-John Agnew," HHP.

35. Clipping, New York Evening Post, 18 December 1931, "Misrepresentations file-Democratic National Committee," HHP.

36. Rickard to Richey, 20 February 1932, "Misrepresentations file-Lawrence Richey," HHP. 
Current Example of What We Do to Our Presidents," appeared in the February Collier's to the delight of the Hoover supporters and to a warm press reception. ${ }^{37}$ The article was adroitly written, evoking sympathy for the president but stopping short of melodrama. Train appealed to the public's sense of fair play by stating that whatever one thought of Hoover as president, he at least deserved fair assessment of his pre-presidential career. Train continued to compare Hoover to Washington, Jefferson, Jackson, Wilson, and especially Lincoln, all of whom had served in times of national crisis and had been subject to vilification by contemporaries. In an effort to discredit the authors and publishers of the smear books, Train detailed the history of O'Brien, Hamill, Roth, and Liggett. Complete with a photograph of Belgium's King Albert, on which the monarch wrote of his warm regard for Hoover, the Train article represented the high point of the Hooverites' refutation campaign.

Hoover's supporters proceeded nonetheless with their lengthy dissertation on the attacks on the president. This decision was fortified when George Barr Baker in February 1932 obtained a confession from John Hamill that his book was an utter lie. ${ }^{38}$ This confession was soon elaborated into a 188-page affidavit signed by Hamill on June 4, 1932. Although Hamill swore in the affidavit that he had written it without aid or coercion, it seems unlikely that Hamill was the author. The detailed information strongly suggests that the author was someone with an intimate knowledge of Hoover's past, knowledge that Hamill had already denied possessing; George Barr Baker would have been a more likely author. ${ }^{39}$ The affidavit exposed the sordid relationship between $O^{\prime}$ Brien and Hamill, described Hamill's manufactured evidence against the president, explicitly repudiated The Strange Career of Mr. Hoover and the other smear books, and unabashedly apotheosized Hoover.

With Hamill's affidavit on file, the refutation campaign in 1932.

37. Train's article was published in book form by the John Day Company

38. Rickard diary, 17 February 1932; John Hamill, affidavit (see fn 9). The origin of this confession is obscure, although some evidence suggests that Baker might have employed strong-arm tactics in dealing with Hamill. See Memorandum, 26 October 1931, "Misrepresentations file-Hamill," HHP; transcript, Morton Blumenthal interview, 8 December 1966, Hoover Library.

39. Rickard diary, 26 March 1932. 
concluded with publication of. Herbert Corey's The Truth About Hoover. In essence, this book was an augmented and more poorly phrased reiteration of Train's article. Corey painstakingly traced Hoover's career, panegyrizing the president's many accomplishments, and systematically exploding the voluminous charges levied against him. Corey dismissed the Hamill book with some scathing irony: "I think that I must discontinue the practice of saying that Hamill did not tell the truth in this or that story. It will be much more satisfactory to report when Hamill tells the truth. Very much less laborious too." ${ }^{40}$ In his defense of Hoover, Corey was less successful than Train had been in avoiding the maudlin and the inconsequential. He, for example, attempted to discredit Hamill by intimating that he was unclean, that "... he wears his shirts several days." And he praised Hoover because "all his long life, in defiance of the rules of optometrics, he has read in bed."

Even the most sanguine Hoover supporter could not have been very pleased with The Truth About Hoover; Edgar Rickard certainly was not. Rickard confessed that the book hardly warranted the time and effort involved in its publication. This feeling was undoubtedly reinforced when one of the smear authors, Walter Liggett, sued Herbert Corey and his publisher, Houghton Mifflin \& Company, for defamation of character. This ironic case seems never to have reached court-Liggett was murdered in a gang-land killing in Minneapolis in 1935. ${ }^{41}$

Enthusiasm for the refutation effort waned after Hoover's loss to Franklin Roosevelt in the November election. Still Hoover's die-hard supporters did not unceremoniously forsake their leader; they attempted to buy and dispose of as many of the smear books as possible-some were purchased for as much as fifty dollars per copy. Rickard especially remained solicitous of Hoover's place in history and endeavored to disseminate the true story of Herbert Hoover to the future generations of Americans: he sent free copies of Corey's book to major libraries and high schools throughout the country. ${ }^{42}$

40. Herbert Corey, The Truth About Hoover (New York, 1932), 109.

41. Rickard to Richey, 6 February 1933, "Misrepresentations file-Lawrence Richey," HHP; Rickard diary, 26 March 1932.

42. Transcript, Blumenthal interview. 


\section{Hoover and the Smear Books}

Thus the curious history of Herbert Hoover and the smear books ended. Will Irwin, a fiercely loyal Hooverite, would later, with the wisdom of hindsight, admit that the smear books were notable chiefly as curiosities and undoubtedly enjoyed a limited circulation. On the whole, the books were so badly written, tediously redundant, and given to gross misstatements that few people probably heeded them at all. If this was the case, why did Hoover and his supporters undertake such a timeconsuming and ultimately ineffective campaign to refute the unfounded charges? The refutation campaign of 1932, must be seen, in part, as the culmination of frustration produced by over a decade of alleged misrepresentations of Hoover. Hoover's personality was also an important factor-his notorious sensitivity and taciturnity which prompted him to rail against what he considered to be unjust criticism. But, perhaps more than anything else. Hoover's relationship with the former members of the Commission for the Relief of Belgium predetermined the reception that the smear books would be accorded. In this sense, it is difficult to fault too heavily a campaign, however misguided, which was engendered by such a sense of mutual loyalty and respect. 
Copyright of Annals of Iowa is the property of State of Iowa, by \& through the State Historical Society of Iowa and its content may not be copied or emailed to multiple sites or posted to a listserv without the copyright holder's express written permission. However, users may print, download, or email articles for individual use. 